\title{
Ultrasonographical features and cytological findings of thyroid nodules in patients with Hashimoto thyroiditis
}

\section{Didem Ozdemir ${ }^{1}$, Fatma Dilek Dellal' ${ }^{1}$, Husniye Baser ${ }^{1}$, Aylin Kılıc Yazgan², Seyda Turkolmez ${ }^{3}$, Reyhan Ersoy ${ }^{1}$, Bekir Cakir ${ }^{1}$}

${ }^{1}$ Ankara Yildirim Beyazit University, School of Medicine, Ataturk Education and Research Hospital, Department of Endocrinology and Metabolism, Ankara, Turkiye

${ }^{2}$ Ankara Yildirim Beyazit University, School of Medicine, Ataturk Education and Research Hospital, Department of Pathology, Ankara, Turkiye

${ }^{3}$ Ankara Yildirim Beyazit University, School of Medicine, Ataturk Education and Research Hospital, Department of Nuclear Medicine, Ankara, Turkiye

Introduction:

It is unclear whether ultrasonographic (US) features and fine needle aspiration biopsy (FNAB) results of nodules associated with Hashimoto thyroiditis (HT) are affected by the presence of thyroiditis or not. It is recommended to evaluate and manage these nodules like the ones in patients without HT. In this study, we aimed to compare US features and cytological results of nodules in patients with and without HT.

\section{Description of Methods:}

Patients who underwent FNAB under US guidance in our clinic in a period of 4 months were evaluated prospectively. US features of nodules were recorded in all patients. Diagnosis of HT was made depending on the clinical, laboratuary and US features of parenchyma. Nodules in patients with and without HT were divided into Group 1 and Group 2, respectively. Cytologically, nodules were classified as benign, atypia of undetermined significance/follicular lesion of undetermined significance (AUS/FLUS), suspicious for follicular neoplasia, suspicios for malignancy, malignant and nondiagnostic. A nodule with at least two consequent inadequate biopsy result was defined as nondiagnostic

\section{Results:}

$181(35.5 \%)$ patients with HT (166 female and 15 male) ad 329 (64.9\%) patients without HT were included in the study.

Totally, 800 nodules in these 510 patients were evaluated. Mean age of patients with HT was higher than patients without HT (50.6 \pm 12.2 and $46.7 \pm 12.0$, respectively, $\mathrm{p}=0.001)$. Patients with HT had significantly higher rates of antibody positivity and hypothyroidism compared to patients without HT $(\mathrm{p}<0.001) .288(36 \%)$ of 800 nodules were included in Group 1 and $512(64 \%)$ were included in Group 2. Ultrasonographical features of nodules in patients with and without HT are given in table 1. Longest diameter of nodules in Group 1 was significantly higher than nodules in Group $2(p<0.001)$. Ultrasonographically, presence of hypoechoic halo and marginal irregularity were similar in two groups $(\mathrm{p}=0.12$ and $\mathrm{p}=0.20$, respectively). Microcalcification was present in $11.8 \%$ of nodules in Group 1 and $20.3 \%$ in Group $2(p=0.002)$.

Macrocalcification was detected in $19.5 \%$ of nodules in Group 1 and $23.8 \%$ of nodules in Group $2(\mathrm{p}=0.01) .30 .8 \%$ of nodules in Group 1 was hypoechoic, $66.4 \%$ was isoechoic and $2.8 \%$ was hyperechoic.
In Group 2, $38.9 \%$ was hypoechoic, $59.6 \%$ was isoechoic and $1.4 \%$ was hyperechoic $(\mathrm{p}=0.01)$. Solid texture was observed in $78.5 \%$ of nodules in Group 1 and $61.7 \%$ of nodules in Group $2(\mathrm{p}<0.001)$. Cytological results were similar in two groups $(\mathrm{p}=0.43)$ (Table 2).

Table 1: Ultrasonographic features of nodules with and without Hashimoto thyroiditis

\begin{tabular}{|c|c|c|c|}
\hline & $\begin{array}{c}\text { HT }(+) \\
n=288(36 \%)\end{array}$ & $\begin{array}{c}\text { HT }(-) \\
n=512(64 \%)\end{array}$ & $\mathbf{p}$ \\
\hline Diameter (mm) & $14.10 \pm 6.26$ & $16.80 \pm 10.10$ & $<0.001$ \\
\hline $\begin{array}{c}\text { Peripheral halo: } \\
\text { Present } \\
\text { Absent }\end{array}$ & $\begin{array}{l}37.2 \%(107) \\
62.8 \%(181)\end{array}$ & $\begin{array}{l}32.4 \%(166) \\
67.6 \%(346)\end{array}$ & 0.176 \\
\hline $\begin{array}{c}\text { Microcalcification: } \\
\text { Present } \\
\text { Absent } \\
\end{array}$ & $\begin{array}{c}11.8 \%(34) \\
88.2 \%(254)\end{array}$ & $\begin{array}{l}20.3 \%(104) \\
79.7 \%(408)\end{array}$ & 0.002 \\
\hline $\begin{array}{c}\text { Macrocalcification } \\
\text { Present } \\
\text { Absent } \\
\end{array}$ & $\begin{array}{c}19.5 \%(56) \\
80.6 \%(232)\end{array}$ & $\begin{array}{l}23.8 \%(122) \\
76.2 \%(390)\end{array}$ & 0.012 \\
\hline $\begin{array}{l}\text { Regular margins } \\
\text { Irregular margins }\end{array}$ & $\begin{array}{l}30.6 \%(88) \\
69.4 \%(200) \\
\end{array}$ & $\begin{array}{l}36.3 \%(186) \\
63.7 \%(325) \\
\end{array}$ & 0.187 \\
\hline $\begin{array}{l}\text { Hypoechoic } \\
\text { Isoechoic } \\
\text { Hyperechoic }\end{array}$ & $\begin{array}{l}30.8 \%(88) \\
66.4 \%(190) \\
2.8 \%(8)\end{array}$ & $\begin{array}{c}38.9 \%(190) \\
59.6 \%(291) \\
1.4 \%(7)\end{array}$ & 0.01 \\
\hline $\begin{array}{l}\text { Solid } \\
\text { Cystic } \\
\text { Mixed }\end{array}$ & $\begin{array}{c}78.5 \%(226) \\
0.7 \%(2) \\
20.8 \%(60)\end{array}$ & $\begin{array}{c}61.7 \%(316) \\
4.7 \%(24) \\
33.6 \%(172)\end{array}$ & $<0.001$ \\
\hline
\end{tabular}

Table 2: Cytological results of nodules in patients with and without Hashimoto thyroiditis

\begin{tabular}{lccc} 
& $\begin{array}{c}\text { HT (+) } \\
\mathbf{n = 2 8 8 ( 3 6 \% )}\end{array}$ & $\begin{array}{c}\text { HT (-) } \\
\mathbf{n}=\mathbf{5 1 2}(\mathbf{6 4 \% )}\end{array}$ & $\mathbf{p}$ \\
\hline Benign & $80.2 \%(231)$ & $80.9 \%(414)$ & \\
AUS/FLUS & $3.8 \%(11)$ & $3.3 \%(17)$ & \\
Suspicios for follicular & - & $1.0 \%(5)$ & \\
neoplasia & & $1.2 \%(6)$ & \\
Suspicios for malignancy & $0.3 \%(1)$ & $1.4 \%(7)$ & \\
Malignant & $1.7 \%(5)$ & $12.3 \%(63)$ & \\
Nondiagnostic & $13.9 \%(40)$ & & \\
\hline
\end{tabular}

\section{Conclusion:}

Suspicious US features such as microcalcification, macrocalcification and hypoechoic appearance are found with a lower prevalence in nodules associated with HT. In these nodules, cytological findings were similar with nodules in patients without chronic thyroiditis. 